\title{
Inspiracja artystyczna, forma znacząca i zaangażowanie ${ }^{\star}$
}

\section{KEY WORDS}

aesthetic experience, disinterestedness, engagement, form, inspiration

\begin{abstract}
Obidzińska Bogna J., Inspiracja artystyczna, forma znacząca i zaangażowanie [Artistic Inspiration, Significant Form and Engagement]. Kultura - Społeczeństwo - Edukacja nr 2(8) 2015, Poznań 2015, pp. 47-58, Adam Mickiewicz University Press. ISBN 978-83-232-3004-5. ISSN 2300-0422

Contemporary aesthetic thought, especially that rooted in the pragmatist tradition and apologetic for the environmental experience, tends to situate form oriented aesthetics in juxtaposition to the concept of the aesthetic engagement. In particular the notion of disinterestedness is often brought to the forefront as connected to the concept of psychic distance and disdain for the surrounding reality. This essay attempts to revise two theories strongly promoting the importance of the physical form of the objects inspiring the aesthetic experience of the artist, namely that of Clive Bell and that of Maurice Merleau-Ponty, in order to respond to the aforementioned criticisms of formalism. In particular, the concept of the perception of the form as an end-in-itself rather than as a means to a heterogenous end is analyzed with reference to its engaging character.
\end{abstract}

I.

Do pojęć z zakresu estetyki, wokół których już od półwiecza nieustająco toczą się spory, zaliczamy odziedziczone po kantowskiej filozofii smaku bezinteresowność i powiązany z nią emocjonalny czy też psychiczny dystans (por. Dickie, 1961: 233-238; Foster, 2010: 14-26). Oba te zagadnienia stawiane są, szczególnie za oceanem, na gruncie neopragmatyzmu, choć nie tylko, pod gradem oskarżeń

* Artykuł został zrealizowany dzięki finansowaniu z grantu NCN Fuga 1 UMO-2012/04/S/HS1/ 00485 . 
o ekskluzywizm i normatywność wobec poszczególnych dziedzin sztuki z jednej strony (Crowther, 2007: 15 i nast.), oraz o wpływ na wykluczenie sztuki z dziedziny życia i służących mu rozmaitych ról (por. Welsch, 2005: 113-119) z drugiej. „Bezinteresowność” postawy estetycznej (the aesthetic attitude) bywa przy tym utożsamiana $\mathrm{z}$ obojętnością, brakiem emocjonalnego i wolitywnego „zaangażowania" w odbiór sztuki, a co za tym idzie - także z brakiem wrażliwości i reaktywności na otaczającą rzeczywistość, włączając środowisko architektoniczne, przyrodnicze i społeczne człowieka (por. Berleant, 2007: 54-71; Berleant, 2012: 39-46). Wypracowane przez Kanta i za nim przez myślicieli dziewiętnastowiecznych (z wyłączeniem nurtu romantycznego) oraz przez brytyjski estetycyzm i modernizm rozumienie postawy estetycznej jawi się z perspektywy pragmatycznej jako skrajnie konceptualne i oparte, z jednej strony, na założeniu o bierności i obojętności podmiotu wobec percypowalnej rzeczywistości, a $\mathrm{z}$ drugiej na uprzywilejowaniu podmiotu względem rzeczywistości, która jest jego domeną.

W niniejszym szkicu proponuję powrócić do myśli formalistycznej Clive’a Bella, podjętej i poprowadzonej dalej przez Maurice’a Merleau-Ponty'ego, aby przyjrzeć się jeszcze raz koncepcji „bezinteresowności” doświadczenia estetycznego z perspektywy wyżej zasygnalizowanych zarzutów. Posłuży temu celowi prześledzenie relacji pomiędzy artystą jako podmiotem a przedmiotami, których formy inspirują go do tworzenia, w ujęciu wymienionych myślicieli.

II.

Według Bella, chociaż twórczość artystyczna odróżnia się dość wyraźnie od przeżycia mistycznego, u swoich źródeł jest jednak do niego nieco zbliżona. Wspólnym źródłem przeżycia mistycznego i inspiracji artystycznej ma być stosunek do rzeczywistości, jaki żywią mistycy i artyści, a który wyrasta z ich zainteresowania rzeczywistością jako taką, s a mą d la si e b i e, co Bell określa „bezinteresownością". Mistyk i artysta w tym ujęciu staje przed rzeczywistością i s t $\mathrm{n}$ i e j ą c ą, niewymagającą uzasadnienia ani rozumowego określenia.

Clive Bell określa ten stosunek jednym wspólnym mianem „ducha religijnego”, który ma charakteryzować się zdolnością do dostrzegania w świecie przedmiotów wich bezwzględnej formie i odróżniania ich od podobnych im, względnych. Bezwzględność przedmiotów charakteryzuje się tym, że traktowane 
są one jako cel sam w sobie. Przeciwieństwem tego jest traktowanie utylitarne, które występuje w stosunku do przedmiotów używanych w większości codziennych aktywności ludzkich. Przedmiotami względnymi są narzędzia, ponieważ zmieniają swoje funkcje zgodnie $\mathrm{z}$ zastosowaniem. Zastosowanie $\mathrm{z}$ kolei zmienia się zależnie od potrzeb użytkownika. Na gruncie tego stanowiska każdy przedmiot można więc traktować bądź utylitarnie (i widzieć go tylko zgodnie $\mathrm{z}$ jego konkretnym zastosowaniem), bądź jako element rzeczywistości samej w sobie, niezależnie od niczego (jedynie, co stało się przedmiotem badań Romana Ingardena nad percepcją estetyczną, zależnie od punktu patrzenia i warunków zewnętrznych przedmiotu, które wpływają na jego wygląd). Zdolność do rozróżniania pierwszej $\mathrm{z}$ wymienionych warstw istnienia przedmiotów od drugiej powoduje dalej odczuwanie większego związku z przedmiotami $\mathrm{w}$ ich warstwie bezwzględnej (Bell, 1958: 63, 67) ${ }^{1}$.

Związek mistyków i artystów z przedmiotami ich otaczającymi widzianymi przez nich $\mathrm{w}$ ich ostatecznej rzeczywistości określić można jako pewien rodzaj szacunku i zachwytu. Przy tym szacunek, jako odpowiednik maiestas i tremendum, przeważa w przeżyciu mistycznym, jako kontakcie z tajemnicą numinosum, gdy tymczasem zachwyt, jako odpowiednik fascinans, przepełnia przeżycie inspiracji artystycznej, choć oczywiście wszystkie trzy elementy występują w obu rodzajach doświadczenia, a w przypadku doświadczenia dzieł odnoszących do uczucia wzniosłości, w znacznym stopniu². Uczucie zachwytu rozbudza w mistyku i artyście potrzebę bezpośredniego kontaktu z przedmiotami go wywołującymi. Kontakt ten polega na specyficznie rozumianym oddawaniu się im $w$ stużbę.

${ }^{1}$ Por. There are things in life the worth of which cannot be related to the physical universe, things of which the worth is not relative but absolute. [63] It is a consciousness of the unconditioned and universal that makes people religious; and it is this consciousness or, at least, a conviction that some things are unconditioned and universal, that makes their attitude towards the conditioned a little unsympathetic. [67]

${ }^{2} \mathrm{~W}$ ujęciu Otto przytoczone kategorie przysługują raczej wyłącznie przeżyciu mistycznemu jako uprzywilejowanemu kontaktowi z Numinosum. Sztuka poprzez takie środki wyrazu, jak wzniosłość, ogrom, wyższość, świetlistość itp. bywa dla Otto skutkiem i przyczynkiem dla przeżycia mistycznego [por. Otto, 1999: 84-90]. My staramy się powiedzieć tu co innego, a mianowicie to, że istnieje pewna istotna analogia pomiędzy obu zagadnieniami, która wymaga przywołania określeń: szacunek i zachwyt. Ta analogia zasadza się w absolutnej inności przedmiotu, z którym zarówno mistyk, jak i artysta wchodzi w kontakt. Ta inność, jak zostanie dalej pokazane, stanowi trzon podejścia artysty do rzeczywistości i wynikającej z niej twórczości. 
W przypadku świętego, mistyka, oddanie się $w$ stużbę przedmiotowi jego zachwytu, Bogu, polega na kontemplacji i ekstazie, czyli bezpośrednim przekroczeniu swej dotychczasowej kondycji bytu cielesnego i wejściu w kontakt z Bogiem. Zachwyt jego odbiega od for m y przedmiotów, których postrzeżenie do tego przeżycia prowadzą, i dociera do zachwytu Bogiem jako Istnieniem Samym, istniejącym mimo formy.

W przypadku artysty jest inaczej. Tym, co według Clive’a Bella w przedmiocie pozostaje stałe, bezwzględne, jest dla artysty i st n i e n i e przedmiotu takim, jakim on jest w swej formie. Bell pisze:

Mistyk odczuwa rzeczy jako „cele” a nie jako „środki do celów”. Pośród przedmiotów poszukuje owej rzeczywistości ostatecznej, która wywołuje uniesienie emocjonalne i jeśli nie dochodzi do niej poprzez czystą formę, istnieją wszak, jak wspominałem, również inne drogi do tej krainy. (Bell, 1958: 62)

Dostrzeżenie for my jako dominującej $\mathrm{w} \mathrm{k}$ a ż dy m przedmiocie, analogicznie do inspiracji mistycznej, jest także źródłem inspiracji artystycznej. Artysta zaczyna od dostrzeżenia postaci przedmiotów świata i pozostaje przy niej. Kontemplacja for my wydobywa z niej oczywistość istnienia świata i podobnie jak w przypadku doświadczenia religijnego, w ujęciu Bella chroni ją, jak i sam świat, przed uprzedmiotowieniem właściwym zarówno stosunkowi utylitarnemu, jak i naukowemu.

Kontakt artysty z formą przedmiotów otaczających go odbywa się poprzez patrzenie. Jest to patrzenie „czyste” odpowiadające pojęciu chaste, czyli wynikające nie z imperatywu zaspokojenia własnej lub czyjejś potrzeby takiej czy innejtakże potrzeby przyjemności zmysłowej lub intelektualnej - ale z odkrycia wartości formalnej przedmiotu w oderwaniu od jego potencjalnych zastosowań (por. Bell, 2007: 80-84)4 . Doświadczenie formy jako znaczącej i przeżycie emocji estetycznej nią inspirowanej polega zatem na uwolnieniu stosunku do przedmiotu od instrumentalności względem celu zewnętrznego wobec przedmiotu samego i postrzeżenia jego obecnej postaci. Bell explicite odnosi się wykluczająco do celów, które na przykład w klasycznej teorii estetycznej Edmunda Burke’a stanowi-

\footnotetext{
${ }^{3}$ Por. The mystic feels things as „ends” instead of seeing them as „means”. He seeks within all things that ultimate reality which provokes emotional exaltation and, if he does not come at it through pure form, there are as I have said, more roads to that country.

${ }^{4}$ Autor jednoznacznie definiuje doświadczenie estetyczne jako takie, które abstrahuje na przykład od miłości, lub innych doświadczeń życia codziennego, takich jak pragnienie podniesienia własnej pozycji społecznej, pragnienie zapewnienia sobie bezpieczeństwa itp.
} 
ły podstawę celów biologicznych, zarówno $\mathrm{w}$ ich wersji negatywnej, stwarzając zagrożenie życia, jak w wersji pozytywnej, dając powód dla pomnożenia życia (por. Burke, 1968: 42-46).

Patrzenie „bezinteresowne” rejestruje, ale nie nazywa, nazywanie bowiem uprzedmiotawia to, co nazywa, automatycznie przypisując rzeczy funkcję. Jedynie powstrzymanie się od nazywania, wejście pomiędzy to, co widziane, i przebywanie wśród tego, co widziane, umożliwia dotarcie do granicy własnej podmiotowości i przedmiotowości źródła doznań. Patrzenie utylitarne, tak, jak jego ideał, czyli patrzenie naukowe, jest związane $\mathrm{z}$ automatycznym nazywaniem.

Patrzenie artysty, aby ulec inspiracji, musi uwolnić się od wszystkiego, co „manipuluje rzeczami i wcale nie chce wśród nich przebywać” (Merleau-Ponty, 1996: 16). Przebywanie wśród rzeczy musi przekroczyć bycie ob ok w takim sensie, $\mathrm{w}$ jakim o b o k przedmiotu jest podmiot nastawiony naukowo. Ten ostatni jest bowiem, według fenomenologa, nie tyle obok, co wobec przedmiotu. Pozycja w o b e c implikuje w dalszej kolejności bycie p o n a d, po s i a $\mathrm{d}$ a n i e. Podmiot, podchodząc do przedmiotu naukowo, bierze go we władanie, a narzędziem jego władzy są nazwy. Mniej lub bardziej skomplikowane - aż po komplikację na poziomie teorii - są one zawsze konstruktami, niekoniecznie przystającymi do świata takiego, jaki on rzeczywiście jest, ale do świata takiego, jakiego pragnie bądź potrzebuje podmiot. Nazwa, w tym toku myślenia, jako twór umysłu stojący w relacji funkcjonalnej do rzeczywistości, narzucana jest przedmiotom w oparciu o ich zastosowanie.

Na gruncie fenomenologii wynikiem tego mechanizmu jest relacja, można rzec, zwrotna, poprzez którą następnie nazwy narzucają ludziom nastawionym do rzeczywistości funkcjonalnie widzenie w przedmiotach jedynie tego, o czym one (nazwy) mówią. A ponieważ nazwy najczęściej odnoszą się do zastosowań, jakie spełniają przedmioty - sprowadzają obserwowane elementy do narzędzi. Odkąd kufer nazywa się kufrem, osobę, która powie o nim „zielona bryła z wybrzuszoną górą odbijająca się żółto na tle fioletowych zasłon", rozpoznaje się jako estetę lub artystę; większość ludzi będzie w kufrze widziała przede wszystkim pojemnik na pościel czy rzeczy cenne - co, jak argumentuje Clive Bell blokuje impuls inspirujący do tworzenia pod wpływem obecności danego przedmiotu.

Dla większości ludzi pr zekrocze ni e tej narzucającej się usilnie funkcji przedmiotów jest na tyle nieosiągalne, że zwykle nie są oni w stanie od razu za- 
mienić jednej funkcji przedmiotu na inną, a przedmioty wielofunkcyjne należą w stechnicyzowanej rzeczywistości do rzadkości (a we wzornictwie ostatnich dekad do awangardy). Spowodowane jest to wieloma czynnikami, w tym marketingowym - większy zysk można osiągnąć, sprzedając serię kolejnych produktów o osobnych funkcjach niż jeden wielofunkcyjny. Propozycje rynku propagujące wielofunkcyjność i wielowymiarowość należą więc raczej do marginesu gospodarki, do „alternatywnych” stylów życia i przywiązania do prostoty, oszczędności i naturalności. Jednym z nielicznych przykładów wielofunkcyjności jest współczesny telefon, pełniący zarazem funkcję aparatu fotograficznego, punktu dostępu do płatności bankowych, nawigatora, dyktafonu, edytora tekstów, poczty, wagi, latarki itd. Ten rodzaj wielofunkcyjności - nowy w gospodarce - przybliża do opisywanego "alternatywnego" sposobu życia, ale ponieważ ogranicza go marketing, w innych sferach niż telekomunikacja jest on procesem powolnym, dotyczy raczej doraźnie dawkowanych „odkryć”.

Skutek przeważająco monofunkcjonego nastawienia utylitarnego jest taki, że przyswoiwszy sobie nazwy jako „ludzką” część świata, wśród p r z e d m i o tó w s a m y h, niekoniecznie podlegających „unarzędziowieniu”, szczególnie elementów przyrody pozostających poza kontrolą lub przydatnością do życia, przeciętny człowiek czuje się obco (nie dotyczy to przyrody poddanej przemysłowi turystycznemu, rekreacyjnemu i sportowemu, który „ufunkcyjnia” naturę).

Paradoksalnie, kultury, w których iunctium pomiędzy przedmiotem a jego nazwą przyjmowane jest za ontologiczne (por. Frazer, 1965: 221-231), bliższe są w swoim doświadczeniu rzeczywistości postrzeganiu przedmiotó w samy ch, czyli ich formy. Nawet badając świat, ludzie należący do tych kultur są (lub byli, w przypadku kultur już nieistniejących) w stanie przebywać wśr ód przedmiotów w znaczeniu bliskim opisanemu wcześniej. Świadczą o tym liczne ustalenia dotyczące światopoglądów wyznawców religii archaicznych, którzy pozaludzkim elementom świata przypisują intencjonalność, a nawet numinotyczność - niekoniecznie na zasadzie hierofanii, ale wprost. To same elementy świata narzucają ludziom należącym do danej kultury archaicznej sposoby postrzegania ich, jako równych ludziom lub nawet ważniejszych od ludzi i przekraczających funkcjonalność pochodzenia od-człowieczego (por. e.g. Eliade, 1966: 156-187; Eliade, 1994: 78-104; Eliade, 1970: 56 i nast., 132 i nast.). Heidegger, przypominając o presokratejskim pozwoleniu rzeczom wy-darzać się, nawołuje właśnie do powrotu do pierwotnej relacji z rzeczywistością, która istniejąc znajdując się w zasięgu poznającego umysłu - od-daje się mu, a więc oddziaływa 
i przekracza alienację i obcość. „Ze wszystkich bytów jedynie człowiek doświadcza, gdy woła doń głos bycia, cudu nad cudy: ż e byt jest. Powołany przeto $\mathrm{w}$ swej istocie do prawdy bycia, człowiek jest zatem zawsze $\mathrm{w}$ pewien istotny sposób nastrojony" (Heidegger, 1999: 226). Tym nastrojeniem, prócz trwogi, na którą zwraca uwagę Heidegger, jest towarzyszące trwodze fascinans. Przekładając myśl Heideggera na relację estetyczną, nastrojenie człowieka odpowiadającego na głos bycia prowadzi poprzez zachwyt do usunięcia siebie jako operującego na przedmiotach podmiotu na drugi plan, w tło. Z praktycznego subiectum, w skutek doświadczenia estetycznego na powrót staje się upokeimenon - „leżącym w tl e" rzeczywistości, którą postrzega (Heidegger, 1997: 76-77).

W nowożytności premodernistycznej artysta jest osobą, która praktykuje tego typu obecność wśr ód i, odwrotnie niż potem oświeceniowy podmiot, staje się dla rzeczywistości upokeimenon. Artysta postrzega rzeczywistość jako owo Heideggerowskie „wołanie głosu bycia” i, nastrajając się pod wpływem jego sensu, z e st raja się z rzeczywistością. W ten sposób, według filozofa, artysta pozwala światu pozostać światem i obrazem czyni jedynie obraz. Twórca nie stara się, jak naukowiec, obejmować rzeczywistości w pojęciach, co sprowadza jego rolę do „tworzenia światoobrazu”. Malarz lub rzeźbiarz wchodzi w nową relację z rzeczywistością otaczającą, polegającą na kontakcie przedpojęciowym z przedmiotami. Maurice Merleau-Ponty opisuje tę relację w następujący sposób, odnosząc się do jednego ze skutków omawianego nastawienia, mianowicie zdystanowania się także od emocji i postaw związanych z praktycznym, zaangażowanym funkcjonowaniem człowieka w świecie:

bez jakiejkolwiek innej „techniki” poza tą, jakiej sobie użyczają jego oczy i jego ręce wskutek nieustającego patrzenia, nieustającego malowania, wydobywający zawzięcie ze świata, w którym głośno od skandali i glorii historii, płótna, które nie dodają nic ani do złości, ani do nadziei ludzkich. (Merleau-Ponty, 1996: 20)

Aby tego dokonać, artysta musi uwolnić się od postawy badacza kartezjańskiego. Nie może po kartezjańsku wątpić w swoje doznania i szukać dla nich uprzedniej podstawy racjonalnej. Operacje, jakich dopuszcza się na przedmiocie kartezjański podmiot, polegające na uznaniu jedynie tych jakości przedmiotu, które widziane, mogą zostać „potwierdzone” przez matematykę - jak rozciągłość, tekstura itp. - po pierwsze, odmawiają przedmiotowi jego niezawisłego istnienia jako niezależny byt, sprowadzając go do pozycji korelatu poznania intelektualnego, a po drugie, jak zauważa Merleau-Ponty, odbierają wzrokowi zdolność widzenia głębi (Merleau-Ponty, 1996: 33-37). Według niego od czasów 
Kartezjusza świat dla nauki, choć jest trójwymiarowy, nie udostępnia tej zdolności wzrokowi. W nowożytności wzrok widzi płasko i dopiero użycie innych zmysłów oraz rekonstrukcja $\mathrm{w}$ umyśle danych pochodzących od nich, umożliwia dotarcie do bryły i przestrzeni.

Patrzenie naukowe stawia więc patrzącego przed płaszczyzną świata $w$ dwóch znaczeniach. Po pierwsze, trójwymiarowość bez udziału rozumu staje się niedostępna zmysłom. Po drugie, świat zostaje sprowadzony do korelatu „x” manipulacji intelektualnych - dopełnienia Levinasowskiej całości $i^{5}$, co Heidegger określa światoobrazem.

Wzrok artysty, w argumentacji Merleau-Ponty’ego, przerywa całość złożoną z podmiotu i świata jako jego negatywności. Wzrok artysty burzy światoobraz. Mówi o tym, że przebywa się $w$ świecie, a nie przed światem. Świat tym samym staje w o k ó 1 artysty, a nie tylko p r zed nim (Merleau-Ponty, 1996: 47).

Zadaniem artysty jest również przywrócić wzrokowi jego pierwotną moc patrzenia i widzenia wszystkich aspektów formy, które niesie i daje świat materialny. W swoim patrzeniu na przedmioty, aby wi d z i e ć kompletnie, artysta musi przewidywać, a ntycypować wiele jakości w pierwszym spojrzeniu niedostępnych. Gdyby tych jakości chciał doznać za pomocą dotyku, musiałby zbliżać się do obserwowanego przedmiotu w n i e s k o ń c z o n o ść bliskości i nigdy nie osiągnąłby, nie objąłby swoich doznań.

Na przykład, patrzący w naturalnym (nie-estetycznym) nastawieniu nie jest w stanie doświadczyć gładzi liści gałęzi, tak samo jak nie jest w stanie doznać gęstości chmur czy sprężystości włosów modelki, ponieważ przypisuje je zmysłowi kontaktu, dotykowi. Wymienione jakości tworzą tymczasem for $\mathrm{m}$ ę, która jako całość i sama w sobie interesuje artystę. Artysta, patrząc jedynie za pomocą oczu, widzi nie tylko nimi, ale całym swoim ciałem, dla niego „nie istnieje rozróżnienie dotyku i wzroku. (...) Wi d zi [ - ] głębię, aksamitność, miękkość, twardość przedmiotów. Cezanne mówił nawet - ich zapach" (Merleau-Ponty, 1996: 81). Dzięki światłu, które działa na odległość, już nie sprowadzone do dziatania opartego na kontakcie (Merleau-Ponty, 1996: 47), artysta, choć nadal jest

\footnotetext{
${ }^{5}$ Całość w ujęciu Levinasa obejmuje podmiot jako przeciwstawny światu kraniec relacji obejmowania, obiektywizacji świata. To powoduje, że „(..) terminy można ujmować bez różnicy od strony lewej do prawej albo od prawej do lewej [co] tworzy z nich, z jednego i drugiego parę. Dopełniają się one wówczas w obrębie widzialnego z zewnątrz systemu”. Oznacza to zatracenie statusu Ja jako autonomicznego bytu w równej mierze, co ogranicza inność innego. Zatem nie tylko inne, ale oba krańce relacji stają się negatywnościami (por. Levinas, 1998, 21).
} 
skazany na wzrok, potrafi dostrzegać i skupiać w sobie również wszystkie inne jakości - w ten sposób wzrok transcenduje sam siebie.

Przed artystą otwiera się swego rodzaju nieskończoność świata, którą on swoim wzrokiem penetruje i podziwia, nie starając się jej ujmować w c ało ść za pomocą umysłu. Dzieje się to za przyczyną wyobraźni, która z b i e r a jakości świata w pierwotnym znaczeniu zbierania (lego) - zanim słowo to zaczęło oznaczać również mówienie i wyrastające zeń nazywanie ${ }^{6}$. Z b i e r an i e jakości formalnych rzeczywistości przez wyobraźnię artysty tu jest bowiem rozpisane na czasową nieskończoność, przez co wykracza poza jednostkowe uczestnictwo artysty $\mathrm{w}$ danym środowisku. Tym samym transcenduje również życie $\mathrm{w}$ jego przekroju czasowym.

„Rozpisane na wieczność” doświadczanie zmysłowe przestaje być doznawaniem zakładającym bierność zmysłów - a szczególnie zmysłu wzroku, utożsamianego przez pragmatystów z dystansem. Siła wzroku artysty polega w tym ujęciu na wprawieniu zmysłów i wyobraźni w ru ch, w działanie. W oświeceniowo-naukowym rozumieniu roli zmysłów, a przede wszystkim wzroku, w poznawaniu świata rzeczywiście krył się paradoks: zarówno według racjonalistów, jak i empirystów, wzrok i inne zmysły biernie „czekały” na to, by przedmioty dostarczyły im d a n y $\mathrm{ch}^{7}$. Same nieruchome, na podobieństwo wosku odbierały odcisk kształtów świata. Jednak świat przedmiotów również określany był jako bierny, oddziaływał nie dzięki swojej zdolności oddziaływania, ale przygodnie, ze względu na tak, a nie inaczej przez umysł ustalone rozumienie struktury zmysłów. To sprawiało, że podmiot nie był podmiotem intencjonalnym, ale podmiotem skazanym na odbiór przygodnie dochodzących do niego treści. Przedmioty natomiast pozostawały dla doznającego podmiotu jedynie korelatami jego doświadczenia, a nie autonomicznymi elementami świata. Zatem doświadczenie świata przechodzące przez zmysły polegało na bierności obu stron - tak przedmiotów, jak i zmysłów. Aktywny pozostawał jedynie umysł pracujący nad obiema stronami: doświadczaniem świata przez zmysły i konstrukcją przedmiotów.

\footnotetext{
${ }^{6}$ Nie chodzi tu o nazywanie w sensie ekspresji pierwotnej (por. Merleau-Ponty, 1999: 108) ale o nazywanie, które zapomniało wspólne wszystkim Grekom pojęcie en, zamienione na łacińską actualitas (por. Heidegger, 1997: 300).

${ }^{7}$ Wyjątkiem być może są teorie - wywodzące się głównie ze średniowiecznych interpretacji Platońskiego Timaiosa - o wewnętrznym świetle wychodzącym z oka na świat i łączącym się ze światłem zewnętrznym. Podobne teorie królowały w średniowieczu; jednak od czasu Leonarda i innych badaczy renesansowych oko „czeka” na „wchodzące” doń obrazy.
} 
Artysta na gruncie formalizmu i Merleau-Ponty'ańskiej fenomenologii funkcjonuje natomiast $\mathrm{w}$ świecie przedmiotów podobnie, można powiedzieć, do władcy w społeczeństwie. Artysta doznaje inspiracji, gdy nakaże swojemu umysłowi porzucić jego nadrzędne stanowisko „oczekującego wizyty [pod]d a n y c h (objects) monarchy”, i „wyjdzie im na spotkanie”. Aby „wybrać się na spotkanie” swych [pod]d a n y ch rozproszonych po świecie i dostrzec najprawdziwszy modus ich funkcjonowania $\mathrm{w}$ rzeczywistości, zasadę ich istnienia, umysł-monarcha musi się do nich upodobnić, nie tylko zewnętrznie, ale przede wszystkim wewnętrznie - musi porzucić wszystkie swoje dotychczasowe przekonania o [pod]d a n y c h. W ten sposób pozna siebie jako jednego z nich. Ich zaś pozna już nie jako swoich [pod]d a n y ch, ale jako obiektywnych ws pół-danych. Wracając ze swej „wędrówki” na „tron”, będzie „monarchą” podmiotów - wzorem władców brytyjskich którzy swoich poddanych określają mianem „subjects”.

Podobnie zachowuje się bellowski i merleau-ponty’ański artysta. Aby przekroczyć swoją cielesność, twórca musi najpierw poznać siebie jako ciało wśród innych ciał. Pozostając, wzorem postulatów ontologii kartezjańskiej, umysłem wśród ciał, nie „zstąpi z tronu”. Poznanie poprzez ciało umożliwia artyście dalej dostrzeżenie innych ciał jako współ-ciał i danych o nich jako współ-danych. Aktywny podmiot staje wobec przedmiotu, który pozostając w centrum, nieruchomy, prawdziwie działa i w ten sposób już nie jest tylko przedmiotem ale przekracza przedmiotowość i staje w prawdziwej relacji obustronnej; jak pisze Merleau-Ponty: „rzeczy postrzeganej nie odnajdujemy ani nie rekonstruujemy na podstawie danych zmysłowych, lecz istnieje ona jako centrum, z którego promieniują bodźce zmysłowe" (Merleau-Ponty, 1999: 108). Świat i n s p i r u j e, tj. „użycza siebie”, swoich jakości, za sprawą tego, że artysta użycza światu swego ciała. Na tym polega służba artysty.

Jak zostało zasygnalizowane wcześniej, według Bella poznanie jakości cielesnych jest poznaniem świata prezentującego się jako forma, która jest znaczaca. Oznacza to, że gdy zmysły, za przyczyną wyobraźni, uaktywniają się i spotykają przedmiot, pozwalają mu oddziaływać poprzez to, ż e jestoraz to, jaki jest, nie zaś przez to, do czego służy. Owo jest uobecniające się w przedmiocie za pomocą jego widzialnej postaci stanowi dla artysty granicę widzialnego i niewidzialnego, którą przekracza, tworząc dzieło, ciągnąc niejako owo je st w nową widzialną formę. W tym momencie jednak proces się zaczyna, nie kończy. Artysta nie jest $\mathrm{w}$ stanie $\mathrm{w}$ żadnym dziele oddać obecności przedmiotu postrzeganej w jego formie, ale ciągle go poszukuje i nieustannie je przekracza w kolejnych 
pracach. Przed artystą otwiera się w ten sposób otwarty projekt, a jego „zetknięcia z przestrzenią są też zetknięciami z trwaniem" (Merleau-Ponty, 1996: 59).

III.

Jak nietrudno zauważyć z powyższej rekonstrukcji, postawa estetyczna, oparta na oderwaniu doświadczenia $z$ jednej strony od emocji egzystencjalnych, jak argumentował Bell, a z drugiej strony od postulatów kartezjańskiego racjonalizmu, jak proponował Merleau-Ponty, nie prowadzi do zobojętnienia podmiotu na rzeczywistość. Krytykowana przez Dickiego w teorii Bullougha „bezinteresowność" nie polega na gruncie formalizmu i fenomenologii na anestetyzacji czy znieczuleniu lub otępieniu wrażliwości zmysłowej lub emotywnej - ale na selekcji specyficznych emocji bądź przestawieniu ich wektora wolitywnego.

O ile pragmatyści domagają się zaangażowania artystów i ludzi nastawionych estetycznie „w sprawy tego świata”, domagają się oni - w kategoriach wyżej omawianych teorii - pozaestetycznego zaangażowania w owe sprawy. Z drugiej strony, formaliści i fenomenologowie postulujący to, co nazywają dystansem bądź bezinteresownością, domagają się autentycznego, wręcz zupełnego i wszechogarniającego zaangażowania podmiotu $\mathrm{w}$ doświadczenie odbieranej rzeczywistości ${ }^{8}$, włączając „sprawy tego świata”, z tym zastrzeżeniem, że zaangażowanie estetyczne czyni z postrzeganych przedmiotów (także spraw, sytuacji, problemów itp.) cel postrzeżenia, nie zaś środek do rozwiązania jednej z rzeczonych „spraw tego świata”. Opisaną postawę określić by należało „bezinteresownym zaangażowaniem" i odróżnić zarówno od skrajnie jej przeciwnej (a zarazem nacechowanej skrajnie anty-aksjologicznie) postawy „interesownej obojętności”, jak i od postawy „bezinteresownej obojętności”, z którą pragmatyści omawianą postawę formalistów mylą, a także od postawy „interesownego zaangażowania”, które sami pragmatyści propagują jako postawę najwłaściwszą nastawieniu estetycznemu do rzeczywistości i środowiska.

\footnotetext{
${ }^{8}$ Myśliciele z kręgu pragmatystów nierzadko przywołują sztuki performatywne, a szczególnie muzykę, jako sferę twórczości zapoznaną przez formalistów, a również jako tę, która najwyraźniej wymaga zaangażowania. Warto przy tym przypomnieć, że dla Bella odbiór muzyki wymagał szczególnego estetycznego zaangażowania i „oczyszczenia” doświadczenia z nacechowania pozaestetycznego, stawiając to doświadczenie na wyróżnionym piedestale estetyczności (por. Bell, 2007: 86).
} 


\section{Literatura}

Bell C. (1958). Art. New York.

Bell C. (2007). Hipoteza estetyczna, przeł. B.J. Obidzińska. „Sztuka i Filozofia” 31.

Berleant A. (2007). Prze-myśleć estetykę. Niepokorne eseje o estetyce i sztuce, przeł. M. Korusiewicz i T. Markiewka. Kraków.

Berleant A. (2012). Art, Nature, Environment. [W:] Aesthetics Beyond the Arts. New and Recent Essays. Farnham/Burlington.

Burke E. (1968). Dociekania filozoficzne o pochodzeniu naszych idei wzniosłości i piękna, przeł. P. Graff. Warszawa.

Crowther P. (2007). Defining Art, Creating the Canon: Artistic Value in an Era of Doubt. Oxford.

Dickie G. (1961). Bullough and the Concept of Psychical Distance. "Philosophy and Phenomenological Research", Vol. 22, No. 2 (Dec.).

Eliade M. (1966). Traktat o historii religii, przeł. J. Wierusz-Kowalski. Warszawa.

Eliade M. (1970). Sacrum, mit, historia, przeł. A. Tatarkiewicz. Warszawa.

Eliade M. (1994). Mity, sny, misteria, przeł. K. Kocjan. Warszawa.

Foster Ch. (2010). Bezinteresowność i pogarda a recepcja głównych myśli Arnolda Berleanta, przeł. M. Bańkowski. „Sztuka i Filozofia” 37.

Frazer J.G. (1965). Złota gałaź. Warszawa.

Heidegger M. (1997). Drogi lasu, przeł. J. Sidorek. Warszawa.

Heidegger M. (1999). Znaki drogi, przeł. K. Wolicki. Warszawa.

Levinas E. (1998). Całość i nieskończoność, przeł. M. Kowalska. Warszawa.

Merleau-Ponty M. (1996). Oko i umysł: szkice o malarstwie, przeł. S. Cichowicz. Gdańsk.

Merleau-Ponty M. (1999). Proza świata: eseje o mowie, przeł. E. Bieńkowska, S. Cichowicz, J. Skoczylas. Warszawa.

Otto R. (1999). Świętość, przeł. B. Kupis. Warszawa.

Welsch W. (2005). Estetyka poza estetyką, przeł. K. Guczalska. Kraków. 